\title{
GENETIC DIVERGENCE IN TUNISIAN CASTOR BEAN GENOTYPES BASED ON TRAP MARKERS
}

\author{
Martin Vivodík, Želmíra Balážová, Zdenka Gálová
}

\begin{abstract}
In the present study, the representatives of the genus Ricinus communis collected from 12 different parts of Tunisia were differentiated by the DNA fingerprinting patterns using 30 TRAP primers. The efficacy of the TRAP technique in this study is further supported by the obtained PIC values of the primers used in the analysis. PCR amplification of DNA using 30 primers for TRAP analysis produced 490 DNA fragments that could be scored in all 56 genotypes of Tunisian castor. The number of amplified fragments varied from 3 (TRAP 04 x arb 1, TRAP $22 \times$ arb 3 and TRAP $23 \times$ arb 3 ) to 13 (TRAP $56 \mathrm{x}$ arb 2), and the amplicon size ranged from 100 to $1600 \mathrm{bp}$. Of the 490 amplified bands, 377 were polymorphic, with an average of 5.71 polymorphic bands per primer. To determine the level of polymorphism in the analysed group of Tunisian castor genotypes polymorphic information content (PIC) was calculated. The lowest values of polymorphic information content were recorded for TRAP $10 \mathrm{x}$ arb 1 (0.555) and the highest PIC values were detected for TRAP $44 \mathrm{x}$ arb $2(0.961)$ with an average of 0.770 . A dendrogram was constructed from a genetic distance matrix based on profiles of the 30 TRAP primers using the unweighted pair-group method with the arithmetic average (UPGMA). According to analysis, the collection of 56 Tunisian castor genotypes were clustered into five main clusters. Moreover, functional TRAP markers would be efficiently useful in genetic studies for castor genetic improvement.
\end{abstract}

Keywords: castor; DNA; dendrogram; PCR; PIC

\section{INTRODUCTION}

Castor bean (syn. castorbean, castor, castor-oil-plant), Ricinus communis $\mathrm{L}$. $(2 \mathrm{n}=20, \mathrm{X}=10)$, is a species of flowering plant in the spurge family, Euphorbiaceae. It is an oilseed crop cultivated mainly in India, Mozambique, Brazil, and China (FAOSTAT, 2014). The seeds of castor bean have around $35-55 \%$ oil, and the commercial standard is $44 \%$. The oil percentage of the seeds varies depending on the cultivation environment and the cultivar (Costa and Ramos, 2004). The hydroxylated fatty acid ricinoleic is approximately $80-90 \%$ of the total fatty acids, which gives castor bean oil (ricin oil) unique chemical and physical properties. Ricin oil is a renewable resource and raw material with various industrial applications (e.g., to manufacture paints, lubricants, cosmetics, pharmaceutical drugs, dyes, anilines, disinfectants, germicides, low-temperature lubricating oils, glues and adhesives, fungicide and insecticide bases, printing inks and varnishes, nylon and plastic), and more recently its use as biodiesel has been explored (Mutlu and Meier, 2010).
Now that some of these lineages have been developed, there is a need to study the genetic divergence among them. The genetic divergence among genotypes of any species can be evaluated with molecular markers, for example, target region amplification polymorphism (TRAP) markers. TRAP markers are functional markers that allow combining fixed and specific primers with arbitrary primers (Hu and Vick, 2003). These markers have high levels of polymorphism, which makes them a promising option for the genotypification of germplasm and identification of genes related to desirable agronomic characteristics. Besides, TRAP markers optimize the genetic gains in genetic improvement programs and are a valuable tool used by these programs to study genetic divergence (Agarwal et al., 2008).

Genetic diversity in castor bean was assessed by using both dominant and codominant molecular markers (random amplified polymorphic DNA, RAPD) (Reddy, Nadigatla and Mulpuri, 2015; Vivodík et al., 2015), inter-simple sequence repeats (ISSR) (Wang et al., 2013; Vasconcelos et al., 2016), start codon targeted (SCoT) (Kallamadi et al., 2015; Reddy, Nadigatla and Mulpuri, 
2015), amplified fragment length polymorphism (AFLP) (Allan et al., 2008; Quintero et al., 2013), simple sequence repeat (SSR) (Gálová et al., 2015; Rukhsar et al., 2017), expressed sequence tag-simple sequence repeats (EST-SSR) (Kanti et al., 2015; Wang et al., 2017), and random microsatellite amplified polymorphic DNA (RMAPD) (Dong et al., 2012), and also advanced molecular markers, such as single nucleotide polymorphism (SNP) (Foster et al., 2010), sequencerelated amplification polymorphism (SRAP) (Lu et al., 2010; Mei-Lian et al., 2012) and methylationsensitive amplification polymorphism (MSAP) (He et al., 2017). The polymerase chain reaction ( $P C R$ ) has been used by many authors, such as Vyhnánek et al. (2015); Bošel'ová and Žiarovská (2016); Ražná et al. (2016); Žiarovská et al. (2017); Simões et al. (2017b); Žiarovská et al. (2018); Ansari et al. (2018); Balážová et al. (2018); El-Fiki and Adly (2019); Žiarovská et al. (2019); Cehula et al. (2019); Vivodík et al. (2019).

\section{Scientific hypothesis}

TRAP markers are polymorphic enough to distinguish individual genotypes of Tunisian castor germplasm.

\section{MATERIAL AND METHODOLOGY}

Fifty-six castor (Ricinus communis L.) genotypes were used in the present study. Seeds of castor were obtained from the University of Carthage, National Institute of Research in Rural Engineering, Waters and Forests (INRGREF), Regional Station of Gabès, Tunisia. The ricin genotypes were obtained from 12 regions of Tunisia: SSouassi (5 genotypes), BT- Bouthay (4 genotypes), GHGhomrassen (5 genotypes), BA- Sidi bou ali (5 genotypes), MT- Matmata (4 genotypes), AG- Mateur (5 genotypes), N- Nefza (4 genotypes), MD- Mednine (5 genotypes), M- Mornag (5 genotypes), G- Gabes (4 genotypes), K- Kebili (5 genotypes), KJ- Ksar jedid (5 genotypes). Genomic DNA of castor cultivars was extracted from leaves of 14-day old plantlets with GeneJET Plant Genomic DNA Purification Mini Kit according to the manufacturer's instructions. DNA concentrations were estimated by UV-Vis spectrophotometer Q5000, Quawell.

Amplification of TRAP fragments was performed according to (Simões et al., 2017a) using decamer arbitrary primers (Table 1 and Table 2). Amplifications were performed in a $15 \mu \mathrm{L}$ reaction volume containing $1.5 \mu \mathrm{L}$ of DNA, $7.5 \mu \mathrm{L}$ of Master Mix (Genei, Bangalore, India), $1.5 \mu \mathrm{L}$ of primer, and $4.5 \mu \mathrm{L} \mathrm{H}_{2} \mathrm{O}$. Amplification was performed in a programmed thermocycler (Biometra, Germany) with the following cycle: $94{ }^{\circ} \mathrm{C}$ for $2 \mathrm{~min}$; 5 cycles at $94{ }^{\circ} \mathrm{C}$ for $45 \mathrm{~s}, 35^{\circ} \mathrm{C}$ for $45 \mathrm{~s}$ and $72{ }^{\circ} \mathrm{C}$ for $1 \mathrm{~min}$; followed by 30 cycles at $94{ }^{\circ} \mathrm{C}$ for $45 \mathrm{~s}, 40^{\circ} \mathrm{C}$ for $45 \mathrm{~s}, 72{ }^{\circ} \mathrm{C}$ for $1 \mathrm{~min}$; and a final extension of $72{ }^{\circ} \mathrm{C}$ for $7 \mathrm{~min}$. Amplified products were electrophoresed in $1.5 \%$ agarose in $1 \times$ TBE buffer. The gels were stained with ethidium bromide and documented using gel documentation system.

\section{Statistical analysis}

A dendrogram based on hierarchical cluster analysis using the unweighted pair group method with arithmetic average (UPGMA) with the SPSS professional statistics version 17 software package was constructed. For the assessment of the polymorphism between genotypes ricin and usability RAPD markers in their differentiation, we used polymorphic information content (PIC) (Weber, 1990).

\section{RESULTS AND DISCUSSION}

In the present study, the representatives of the genus Ricinus communis collected from 12 different parts of Tunisia were differentiated by the DNA fingerprinting patterns using 30 TRAP primers. The efficacy of the TRAP technique in this study is further supported by the obtained PIC values of the primers used in the analysis. PCR amplification of DNA using 30 primers (Table 1 and Table 2) for TRAP analysis produced 490 DNA fragments that could be scored in all 56 genotypes of Tunisian castor (Figure 2 and Table 3). The number of amplified fragments varied from 3 (TRAP $04 \mathrm{x}$ arb 1, TRAP $22 \mathrm{x}$ arb 3 and TRAP $23 \times$ arb 3 ) to 13 (TRAP $56 \times$ arb 2), and the amplicon size ranged from 100 to $1600 \mathrm{bp}$. Of the 490 amplified bands, 377 were polymorphic, with an average of 5.71 polymorphic bands per primer. Results indicated the presence of wide genetic variability among different genotypes of Tunisian castor. To determine the level of polymorphism in the analysed group of Tunisian castor genotypes polymorphic information content (PIC) was calculated. The lowest values of polymorphic information content were recorded for TRAP $10 \mathrm{x}$ arb $1(0.555)$ and the highest PIC values were detected for TRAP $44 \mathrm{x}$ arb 2 (0.961) with an average of 0.770 .

A dendrogram was constructed from a genetic distance matrix based on profiles of the 30 TRAP primers using the unweighted pair-group method with the arithmetic average (UPGMA). According to analysis, the collection of 56 Tunisian castor genotypes were clustered into five main clusters (Figure 1). Cluster 1 contained 2 unique genotypes of Tunisian castor (K-4 and BA-5) from different regions of Tunisia and cluster 2 was divided into two subclusters ( $2 \mathrm{a}$ and $2 \mathrm{~b}$ ). Subcluster $2 \mathrm{a}$ contained 7 genotypes of castor and subcluster $2 \mathrm{~b}$ contained 4 genotypes of Tunisian castor. Cluster 3 contained 6 genotypes of Tunisian castor and cluster 4 was divided into 3 subclusters $(4 a, 4 b$, and 4c). Subcluster $4 \mathrm{a}$ contained 2 genotypes of Tunisian castor and subcluster $4 \mathrm{~b}$ contained 6 genotypes of Tunisian castor and subcluster $4 \mathrm{c}$ contained 29 genotypes of Tunisian castor. (Figure 1).

TRAP markers were used by other authors (Miklas et al., 2006; Hu et al., 2007; Yu et al., 2007; Alwala et al., 2008; Kwon et al., 2010; Yue et al., 2010; Andru et al., 2011; Barakat et al., 2013; Cheng et al., 2013; CrottiFranco et al., 2014; Kumar et al., 2014; Carmo et al., 2015; Feng et al., 2015; Luo et al., 2015; Dias Kanthack Junior et al., 2020). 
Table 1 Characterization of the fixed primers (target region amplification polymorphisms, TRAPs) used to genotype 56 lineages of Tunisian castor bean.

\begin{tabular}{|c|c|c|}
\hline & TRAP Primer & Sequence $\left(5^{\prime}-3^{\prime}\right)$ \\
\hline 1. & TRAP 01 & CCACATCCAGCACCTTTTG \\
\hline 2. & TRAP 02 & TGTGGAGCGTTGAGGATTC \\
\hline 3. & TRAP 03 & TGCTCGCAGGCAAAGATAC \\
\hline 4. & TRAP 04 & TGTCCCATATTTGCCAACG \\
\hline 5. & TRAP 15 & CCGTGATTCTGGTGGTGAG \\
\hline 6. & TRAP 16 & TTACAACTGCGGCATCTCC \\
\hline 7. & TRAP 10 & CGGGTGGCATCAGTTACAG \\
\hline 8. & TRAP 11 & GGCGGATGCTATCTGTGAA \\
\hline 9. & TRAP 22 & CACTCGCCTGTTCAGCACT \\
\hline 10. & TRAP 23 & AGCAAGCCGCACCTAAGAT \\
\hline 11. & TRAP 24 & GTCCAAGCAAAAGCCACCT \\
\hline 12. & TRAP 25 & CCACCAATCCAACGCATAG \\
\hline 13. & TRAP 19 & AATGCCAGCACCTACACCA \\
\hline 14. & TRAP 30 & CTTCTCAGTTGCCCGTTCA \\
\hline 15. & TRAP 31 & CCACCAATGAACCAACTGC \\
\hline 16. & TRAP 32 & TGCCGACTTCTCCTTTCCT \\
\hline 17. & TRAP 35 & CCTCATCATCGTTGCTGCT \\
\hline 18. & TRAP 27 & CGAAATCCTCCTGCTCCTC \\
\hline 19. & TRAP 28 & GCCACCATCTTCACCACAG \\
\hline 20. & TRAP 37 & GCTCACGCACTGGACTCAT \\
\hline 21. & TRAP 39 & GCACCCGAAATCTTCCACT \\
\hline 22. & TRAP 40 & CCACTCAACACCGTTCCAC \\
\hline 23. & TRAP 44 & CGTCCACCCACACTTTCAC \\
\hline 24. & TRAP 46 & CCAGTCACCGTTTGTTGCT \\
\hline 25. & TRAP 49 & TCCTGTCCAATGCTGAACC \\
\hline 26. & TRAP 51 & CCACCGAGAGAGCATACCA \\
\hline 27. & TRAP 52 & GTGGCAAATGCTCACAGGT \\
\hline 28. & TRAP 53 & TACAACTTCGGGTGGTGGA \\
\hline 29. & TRAP 55 & TGATGGAAACCCTTGTGGA \\
\hline 30. & TRAP 56 & CTTGTGCCCTACCAACTGC \\
\hline
\end{tabular}

Table 2 Arbitrary primers used to genotype the 56 lineages of Tunisian castor bean.

\begin{tabular}{ccc}
\hline & Arbitrary primers & Nucleotide sequence (3' - 5') \\
\hline 1. & arb 1 & GACTGCGTACGAATTGAC \\
2. & arb 2 & GACTGCGTACGAATTTGA \\
3. & arb 3 & GACTGCGTACGAATTGCA \\
4. & arb 4 & GACTGCGTACGAATTAATT \\
5. & arb 5 & GACTGCGTACGAATTTGCC \\
6. & arb 6 & GACTGCGTACGAATTGACC \\
\hline
\end{tabular}

Zhang et al. (2013) assessment the genetic diversity and variation of Pinellia ternata collected from 43 populations in China using SRAP $\mathrm{p}$ TRAP markers. A total of 13 SRAP primers in addition to 3 TRAP primer combinations yielded 292 bands in a total of which 286 were polymorphic (98.0\%), with an average of 16 for each. The PIC value ranged from 0.88 to 0.95 , with a mean polymorphic information content (PIC) of 0.92 over all the primers. Luo et al. (2013) developed and characterized sequence tags (ESTs)-simple sequence repeats (SSRs) and targeted region amplified polymorphism (TRAP) markers to examine genetic relationships in the persimmon genus Diospyros gene pool. In total, we characterized 14 ESTSSR primer pairs and 36 TRAP primer combinations, which were amplified across 20 germplasms of 4 species in the genus Diospyros. Liu et al. (2016) study the genetic structure and genetic diversity among and within the 21 populations using target region amplified polymorphism (TRAP) and simple sequence repeat (SSR) markers.
Sixteen pairs of TRAP primers generated a total of 398 fragments, of which $396(99.50 \%)$ were polymorphic; fourteen pairs of SSR primers generated a total of 60 fragments, of which $59(98.33 \%)$ were polymorphic. AlMurish et al. (2013) study efficiency of SRAP, TRAP, and SSR primers in detecting genetic variation among 17 C. arabica genotypes collected from the different valleys of Yafea City, Yemen, and estimate genetic similarity coefficients among these genotypes and classify them according to genetic relationships. The results of the present study demonstrated the presence of genetic variation among coffee genotypes within and between valleys.

In this study, Liu et al. (2015) estimated the genetic relationships within $P$. aibuhitensis using Target Region Amplified Polymorphisms (TRAP) and Amplified Fragment Length Polymorphisms (AFLP) that were derived from related populations on the coasts of China. 
Table 3 Combinations of target region amplification polymorphism (TRAP) primers selected to analyze the polymorphism in 56 lineages of Tunisian castor bean.

\begin{tabular}{|c|c|c|c|}
\hline Combinations & Total fragments & Polymorphism fragments & PIC \\
\hline TRAP $01 \mathrm{x}$ arb 1 & 8 & 6 & 0.896 \\
\hline TRAP $02 \mathrm{x}$ arb 1 & 10 & 8 & 0.689 \\
\hline TRAP $03 x$ arb 1 & 6 & 6 & 0.874 \\
\hline TRAP $04 \mathrm{x}$ arb 1 & 3 & 2 & 0.755 \\
\hline TRAP $15 \mathrm{x}$ arb 1 & 8 & 8 & 0.854 \\
\hline TRAP $16 \mathrm{x}$ arb 1 & 9 & 6 & 0.668 \\
\hline TRAP $10 \mathrm{x}$ arb 1 & 11 & 5 & 0.555 \\
\hline TRAP $11 \mathrm{x}$ arb 1 & 4 & 4 & 0.899 \\
\hline TRAP $22 \mathrm{x}$ arb 1 & 5 & 4 & 0.877 \\
\hline TRAP $23 \mathrm{x}$ arb 1 & 8 & 7 & 0.788 \\
\hline TRAP $24 \mathrm{x}$ arb 1 & 12 & 8 & 0.786 \\
\hline TRAP $25 \mathrm{x}$ arb 1 & 6 & 5 & 0.854 \\
\hline TRAP $19 x$ arb 1 & 5 & 5 & 0.869 \\
\hline TRAP $30 \times$ arb 1 & 9 & 6 & 0.789 \\
\hline TRAP $31 \mathrm{x}$ arb 1 & 9 & 5 & 0.745 \\
\hline TRAP $32 \mathrm{x}$ arb 2 & 7 & 4 & 0.658 \\
\hline TRAP $35 \mathrm{x}$ arb 2 & 7 & 7 & 0.780 \\
\hline TRAP $27 x$ arb 2 & 4 & 3 & 0.754 \\
\hline TRAP $28 x$ arb 2 & 8 & 6 & 0.666 \\
\hline TRAP $37 x$ arb 2 & 11 & 7 & 0.731 \\
\hline TRAP $39 x$ arb 2 & 12 & 9 & 0.591 \\
\hline TRAP $40 \mathrm{x}$ arb 2 & 6 & 6 & 0.781 \\
\hline TRAP $44 x$ arb 2 & 5 & 4 & 0.961 \\
\hline TRAP $46 x$ arb 2 & 9 & 8 & 0.812 \\
\hline TRAP $49 x$ arb 2 & 8 & 8 & 0.739 \\
\hline TRAP $51 \times$ arb 2 & 9 & 6 & 0.630 \\
\hline TRAP $52 \mathrm{x}$ arb 2 & 4 & 3 & 0.891 \\
\hline TRAP $53 x$ arb 2 & 6 & 5 & 0.709 \\
\hline TRAP $55 \mathrm{x}$ arb 2 & 12 & 11 & 0.900 \\
\hline TRAP $56 x$ arb 2 & 13 & 10 & 0.810 \\
\hline TRAP $01 \mathrm{x}$ arb 3 & 11 & 9 & 0.712 \\
\hline TRAP $02 x$ arb 3 & 9 & 9 & 0.890 \\
\hline TRAP $03 \times$ arb 3 & 6 & 5 & 0.731 \\
\hline TRAP $04 x$ arb 3 & 8 & 8 & 0.912 \\
\hline TRAP $15 \mathrm{x}$ arb 3 & 7 & 4 & 0.611 \\
\hline TRAP $16 \times$ arb 3 & 8 & 6 & 0.723 \\
\hline TRAP $10 \mathrm{x}$ arb 3 & 9 & 5 & 0.600 \\
\hline TRAP $11 \mathrm{x}$ arb 3 & 6 & 4 & 0.599 \\
\hline TRAP $22 x$ arb 3 & 3 & 3 & 0.896 \\
\hline TRAP $23 x$ arb 3 & 3 & 3 & 0.879 \\
\hline TRAP $24 x$ arb 3 & 8 & 8 & 0.911 \\
\hline TRAP $25 \mathrm{x}$ arb 3 & 4 & 3 & 0.823 \\
\hline TRAP $19 x$ arb 3 & 4 & 4 & 0.781 \\
\hline TRAP $30 \times$ arb 3 & 5 & 5 & 0.910 \\
\hline TRAP $31 \times$ arb 3 & 5 & 5 & 0.901 \\
\hline TRAP $32 x$ arb 4 & 4 & 3 & 0.801 \\
\hline TRAP $35 \mathrm{x}$ arb 4 & 6 & 5 & 0.780 \\
\hline TRAP $27 x$ arb 4 & 8 & 6 & 0.699 \\
\hline TRAP $28 x$ arb 4 & 9 & 6 & 0.689 \\
\hline TRAP $37 x$ arb 4 & 7 & 4 & 0.609 \\
\hline TRAP $39 x$ arb 4 & 7 & 7 & 0.839 \\
\hline TRAP $40 \times$ arb 4 & 7 & 7 & 0.798 \\
\hline TRAP $44 \mathrm{x}$ arb 4 & 8 & 5 & 0.698 \\
\hline TRAP $46 x$ arb 4 & 11 & 8 & 0.801 \\
\hline TRAP $49 x$ arb 4 & 10 & 6 & 0.639 \\
\hline TRAP $51 \times$ arb 4 & 11 & 7 & 0.709 \\
\hline TRAP $52 x$ arb 4 & 9 & 6 & 0.806 \\
\hline TRAP $53 x$ arb 4 & 6 & 6 & 0.809 \\
\hline TRAP $55 \mathrm{x}$ arb 4 & 5 & 5 & 0.796 \\
\hline TRAP $56 \times$ arb 4 & 4 & 3 & 0.908 \\
\hline TRAP $01 \times$ arb 5 & 4 & 3 & 0.869 \\
\hline TRAP $02 \times$ arb 5 & 8 & 5 & 0.703 \\
\hline TRAP $03 \times$ arb 5 & 7 & 6 & 0.666 \\
\hline TRAP $04 x$ arb 6 & 9 & 5 & 0.599 \\
\hline TRAP $15 \mathrm{x}$ arb 6 & 10 & 5 & 0.669 \\
\hline TRAP $16 x$ arb 6 & 10 & 6 & 0.759 \\
\hline Averages & 7.42 & 5.71 & 0.770 \\
\hline
\end{tabular}

Note: PIC = polymorphism information content 


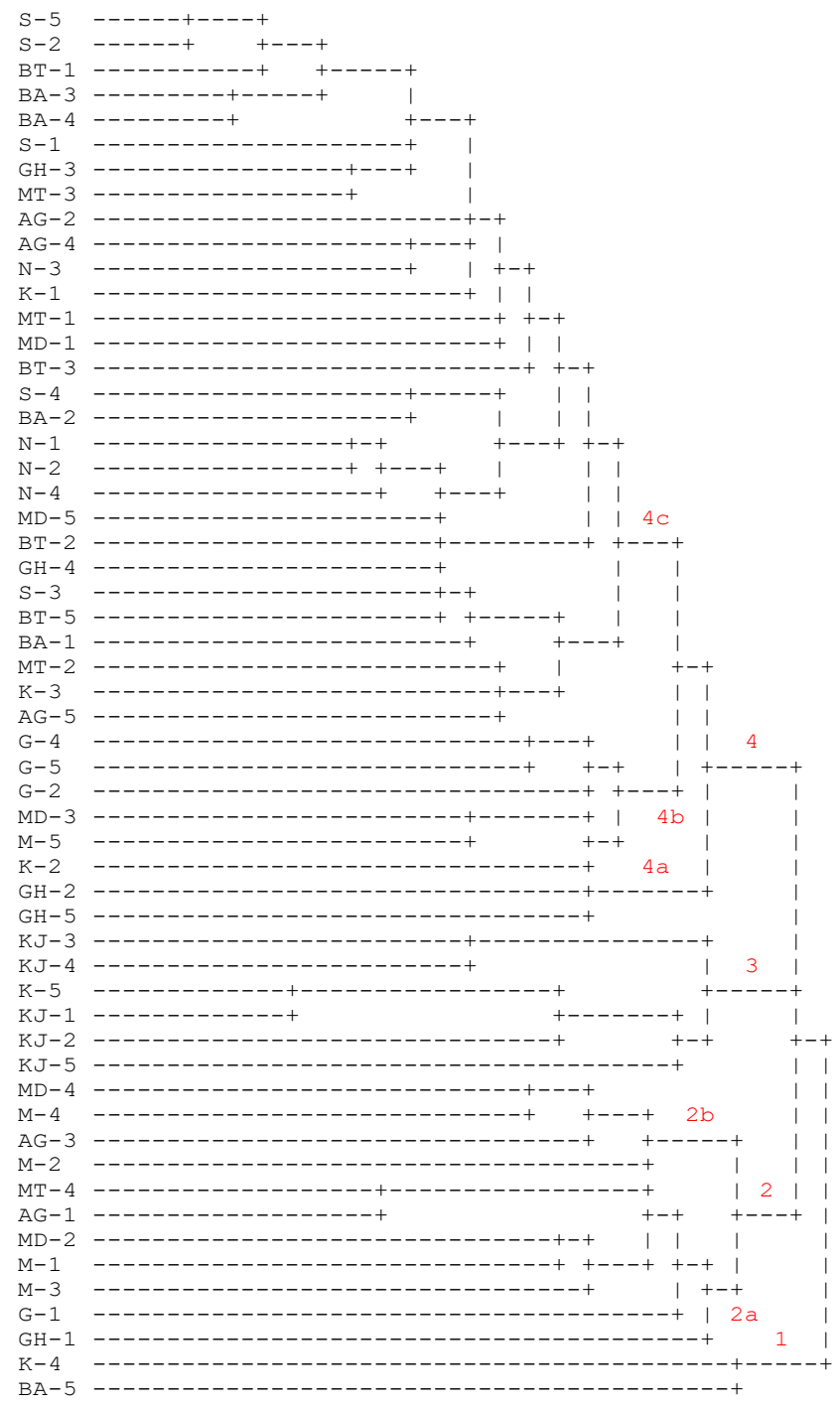

Figure 1 Dendrogram of 56 Tunisian castor genotypes prepared based on 30 TRAP markers. Note: $\mathrm{S}$ - Souassi (5 genotypes), BT - Bouthay (4 genotypes), GH - Ghomrassen (5 genotypes), BA - Sidi bou ali (5 genotypes), MT - Matmata (4 genotypes), AG - Mateur (5 genotypes), N - Nefza (4 genotypes), MD - Mednine (5 genotypes), M - Mornag (5 genotypes), G - Gabes (4 genotypes), K - Kebili (5 genotypes), KJ - Ksar jedid (5 genotypes).
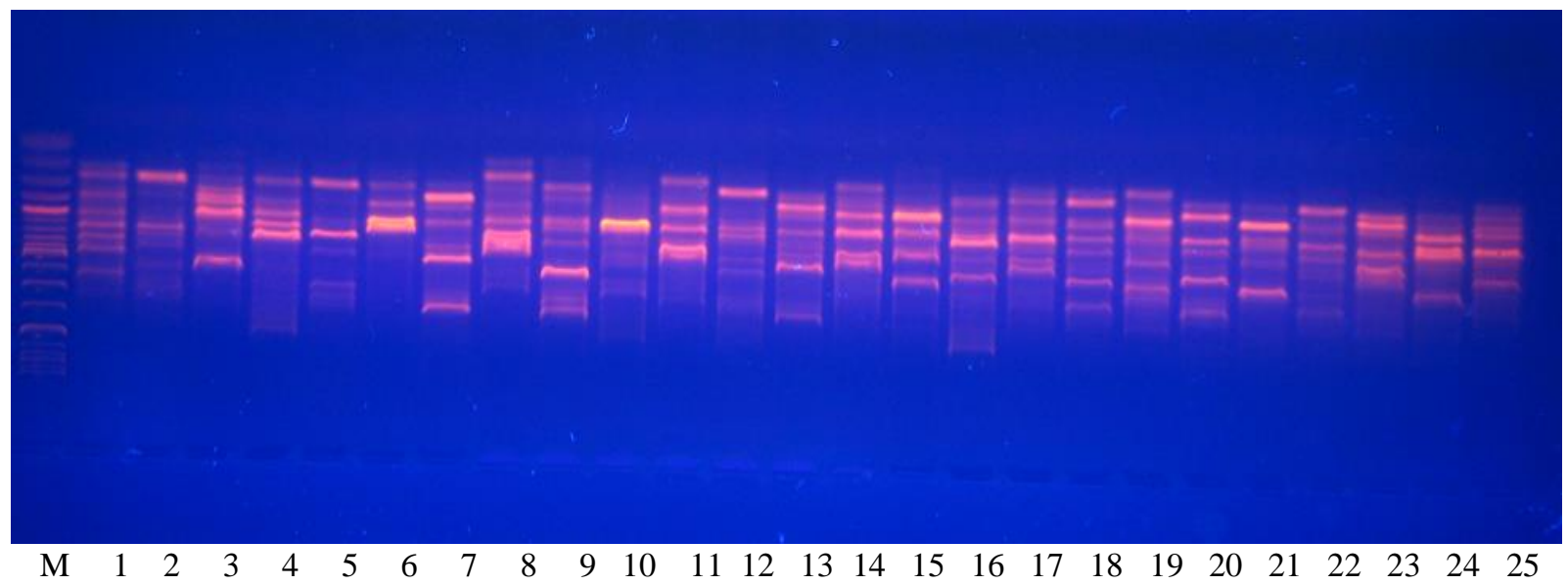

Figure 2 Electrophoretic profile, on $2 \%$ agarose gel, obtained from the amplification of the genomic DNA of 25 lineages of Ricinus communis L.

Note: (lanes 1-25) using TRAP $01 \mathrm{x}$ arb 3 primer. Lane M: 100-bp molecular weight marker. 
Among the TRAPs, 449 bands were observed in total, 439 of which $(97.77 \%)$ were polymorphic between the $P$. aibuhitensis populations and were shared between at least four individuals. The Qinzhou (QZ) population had the highest PPB (78.62\%), and the Dalian (DL) population had the lowest $(60.13 \%)$. The objective of study Farias da Silva et al. (2016) was to analyze the genetic diversity of the clonal germplasm of the guarana plant using Target Region Amplification Polymorphism (TRAP) and Sequence-Related Amplification Polymorphism (SRAP) markers. Sixty clones of the guarana plant were analyzed; 18 were cultivars, eight were similar clones according to morpho-agronomic traits, and 34 were clones of a different origin. Singh et al. (2017) study the genetic variations among the twenty-five sugarcane genotypes employing functional molecular (TRAP) markers. Genetic diversity exists among sugarcane germplasm was exploited to identify promising genotypes bearing enviable agronomic traits (sucrose content and multiple disease resistance). Genetically diversified genotype could be exploited as proven parents in sugarcane hybridization programs to establish a promising cross. Mirajkar et al. (2017) study molecular marker profile using 57 markers, comprising of 27 TRAP and 30 SRAP markers in the gamma ray-induced sugarcane mutants. Collectively these markers produced 260 PCR amplicons among which 147 were polymorphic (56.54\%). The TRAP marker-based analysis showed that the mutants AKTS-01 and AKTS-16 were more diverse (GS $=94$ and 92\%, respectively) than the rest of the mutants. In the study of Fabriki-Ourang and YousefiAzarkhanian (2018) target region amplification polymorphism (TRAP) and conserved region amplification polymorphism (CoRAP) markers were used for genetic diversity and relationship analysis of 25 Salvia ecotypes/species. Twelve TRAP and CoRAP primer combinations (four arbitrary primers and three fixed primers from Salvia miltiorrhiza expressed sequence tag sequences) amplified 180 loci, of which all were polymorphic. Srivong et al. (2019) study 17 sugarcane genotypes from Hawaii and Thailand using 12 target region amplification polymorphism (TRAP) markers and partial Sai nucleotide polymorphism. A total of 275 fragments were produced, of which $273(99.27 \%)$ were polymorphic. The polymorphic information content (PIC) ranged from $0.912-0.959$ with an average value of 0.938. Genetic similarity (GS) by Dice's similarity coefficient ranged from $0.19-0.81$ with a mean of 0.44 .

\section{CONCLUSION}

PCR amplification of DNA using 30 primers for TRAP analysis produced 490 DNA fragments that could be scored in all 56 genotypes of Tunisian castor. The number of amplified fragments varied from 3 (TRAP $04 \mathrm{x}$ arb 1, TRAP $22 \mathrm{x}$ arb 3 and TRAP $23 \mathrm{x}$ arb 3) to 13 (TRAP $56 \mathrm{x}$ arb 2), and the amplicon size ranged from 100 to $1600 \mathrm{bp}$. Of the 490 amplified bands, 377 were polymorphic, with an average of 5.71 polymorphic bands per primer. To determine the level of polymorphism in the analysed group of Tunisian castor genotypes polymorphic information content (PIC) was calculated. A dendrogram was constructed from a genetic distance matrix based on profiles of the 30 TRAP primers using the unweighted pair-group method with the arithmetic average (UPGMA).
TRAP markers could be used to select elite parent genotypes, analysing genetic variation, utilization of genotype potential for trait improvement for adaptation to stress environment. It is therefore suggested that a focused breeding scheme should be adopted while analyzing genome diversity for parent selection to gain maximum value and practical impact on breeding program. TRAP markers exhibited remarkable discriminatory power for genetic diversity analysis.

\section{REFERENCES}

Agarwal, M., Shrivastava, N., Padh, H. 2008. Advances in molecular marker techniques and their applications in plant sciences. Plant Cell Rep., vol. 27, p. 617-631. https://doi.org/10.1007/s00299-008-0507-z

Allan, G., Williams, A., Rabinowicz, P. D., Chan, A. P., Ravel, J., Keim P. 2008. Worldwide genotyping of castor bean germplasm (Ricinus communis L.) using AFLPs and SSRs. Genet. Resour. Crop Evol., vol. 55, p. 365-378. https://doi.org/10.1007/s10722-007-9244-3

Al-Murish, T. M., Elshafei, A. A., Al-Doss, A. A. and Barakat, M .N. 2013. Genetic diversity of coffee (Coffea arabica L.) in Yemen via SRAP, TRAP and SSR markers. Journal of Food, Agriculture \& Environment, vol. 11, no. 2, p. 411-416.

Alwala, S., Kimbeng, C. A., Veremis, J. C., Gravois, K. A. 2008. Linkage mapping and genome analysis in a Saccharum interspecific cross using AFLP, SRAP and TRAP markers. Euphytica, vol. 164, p. 37-51. https://doi.org/10.1007/s10681007-9634-9

Andru, S., Pan, Y. B., Thongthawee, S. Burner, D. M., Kimbeng, C. A. 2011. Genetic analysis of the sugarcane (Saccharum spp.) cultivar 'LCP 85-384'. I. Linkage mapping using AFLP, SSR, and TRAP markers. Theor Appl Genet, vol. 123, p. 77-93. https://doi.org/10.1007/s00122-011-1568-X

Ansari, S., Solouki, M., Fakheri, B., Fazeli-Nasab, B., Mahdinezhad, N. 2018. Assesment of molecular diversity of internal transcribed spacer region in some lines and landrace of Persian clover (Trifolium Resupinatum L.). Potravinarstvo Slovak Journal of Food Sciences, vol. 12, no. 1, p. 657-666. https://doi.org/10.5219/960

Balážová, Ž., Gálová, Z., Vivodík, M., Chňapek, M., Hornyák Gregáňová, R. 2018. Molecular analysis of buckwheat using gene specific markers. Potravinarstvo Slovak Journal of Food Sciences, vol. 12, no. 1, p. 546-552. https://doi.org/10.5219/954

Barakat, M. N., Al-Doss, A. A., Elshafei, A. A., Ghazy, A. I., Moustafa, K. A. 2013. Assessment of genetic diversity among wheat doubled haploid plants using TRAP markers and morpho-agronomic traits. Australian Journal of Crop Science, vol. 7, no. 1, p. 104-111.

Bošel'ová, D., Žiarovská, J. 2016. Direct PCR as the platform of Hedera helix, L. genotypying without the extraction of DNA. Journal of Central European Agriculture, vol. 17, no. 4, p. 941-949. https://doi.org/10.5513/jcea01/17.4.1795

Carmo, C. D., Santos, D. B., Alves, L. B., Oliveira, G. A. F., Oliveira, E. J. 2015. Development of TRAP (Target Region Amplification Polymorphism) as New Tool for Molecular Genetic Analysis in Cassava. Plant Mol. Biol. Rep., vol. 33, p. 1953-1966. https://doi.org/10.1007/s11105015-0887-5

Cehula, M., Juríková, T., Žiarovská, J., Mlček, J., Kysel’, M. 2019. Evaluation of genetic diversity of edible honeysuckle monitored by RAPD in relation to bioactive substances. 
Potravinarstvo Slovak Journal of Food Sciences, vol. 13, no. 1, p. 490-496. https://doi.org/10.5219/1139

Costa, H. M., Ramos, V. D. 2004. Efeito do óleo de mamona em composições de borracha natural contendo sílica. Polímeros: Ciênc. Tecnol., vol. 14, p. 46-50. https://doi.org/10.1590/S0104-14282004000100013

Crotti-Franco, M., de Argollo Marques, D., Siqueira, W. J., Rocha Latado, R. 2014. Micropropagation of Jatropha curcas superior genotypes and evaluation of clonal fidelity by target region amplification polymorphism (TRAP) molecular marker and flow cytometry. African Journal of Biotechnology, vol. 13, no. 38, p. 3872-3880. https://doi.org/10.5897/AJB2014.13649

Dias Kanthack Junior, C. A., Vieira Manechini, J. R., Correa, R. X., Rossini Pinto, A. Ch., Borges da Costa, J., Monteiro Favero, T., Rossini Pinto, L. 2020. Genetic Structure Analysis in Sugarcane (Saccharum spp.) Using Target Region Amplification Polymorphism (TRAP) Markers Based on Sugar- and Lignin-Related Genes and Potential Application in Core Collection Development. Sugar Tech., p. 1-14. https://doi.org/10.1007/s12355-019-00791-0

Dong, H., Wang, C., Li, W., Yang, G. X., Yang, H., Wang, Y. R., Chen, M. H., Li, F. J., Feng, Y., Chen, G. 2012. Castor germplasm diversity analysis using AP-PCR and RMAPD. Acad Period Farm Proc 2012.

El-Fiki, A., Adly, M. 2019. Molecular characterization and genetic diversity in some Egyptian wheat (Triticum aestivum L.) using microsatellite markers. Potravinarstvo Slovak Journal of Food Sciences, vol. 13, no. 1, p. 100-108. https://doi.org/10.5219/978

Fabriki-Ourang, S., Yousefi-Azarkhanian, M. 2018. Genetic variability and relationships among Salvia ecotypes/species revealed by TRAP-CoRAP markers. Biotechnology \& biotechnological equipment, vol. 32, no. 6, p. 1486-1495. https://doi.org/10.1080/13102818.2018.1534555

FAOSTAT. $2014 . \quad$ Available

at:

http://www.fao.org/faostat/en/.

Farias da Silva, E., Barbosa de Sousa, S., Ferreira da Silva, G., Reis Sousa, N., do Nascimento Filho, F. J., Eiji Hanada, R. 2016. TRAP and SRAP markers to find genetic variability in complex polyploid Paullinia cupana var. sorbilis. Plant Gene, vol. $\quad 6, \quad$ p. $43-47$. https://doi.org/10.1016/j.plgene.2016.03.005

Feng, S., He, R., Yang, S., Chen, Z., Jiang, M., Lu, J., Wang, H. 2015. Start codon targeted (SCoT) and target region amplification polymorphism (TRAP) for evaluating the genetic relationship of Dendrobium species. Gene, vol. 567, p. 182-188. https://doi.org/10.1016/j.gene.2015.04.076

Foster, J. T., Allan, G. J., Chan, A. P., Rabinowicz, P. D., Ravel, J., Jackson, P. J., Keim, P. 2010. Single nucleotide polymorphisms for assessing genetic diversity in castor bean (Ricinus communis). BMC Plant Biol., vol. 10, p. 13-18. https://doi.org/10.1186/1471-2229-10-13

Gálová, Z., Vivodík, M., Balážová, Ž., Kut'ka Hlozáková, T. 2015. Identification and differentiation of Ricinus communis L. using SSR markers. Potravinarstvo, vol. 9, no. 1, p. 556-561. https://doi.org/10.5219/516

He, S., Xu, W., Li, F., Wang, Y., Liu, A. 2017. Intraspecific DNA methylation polymorphism in the non-edible oilseed plant castor bean. Plant Divers, vol. 39, no. 5, p. 300-307. https://doi.org/10.1016/j.pld.2017.05.007

Hu, J., Mou, B., Vick, B. A. 2007. Genetic diversity of 38 spinach (Spinacia oleracea L.) germplasm accessions and 10 commercial hybrids assessed by TRAP markers. Genet Resour Crop Evol, vol. 54, p. 1667-1674. https://doi.org/10.1007/s10722-006-9175-4
Hu, J., Vick, B. A. 2003. Target region amplification polymorphism: a novel marker technique for plant genotyping. Plant Mol. Biol. Report, vol. 2, p. 289-294. https://doi.org/10.1007/BF02772804

Cheng, D., Zhang, F., Liu, L., Xu, L., Chen, Y., Wang, X., Limera, C., Yu, R., Gong, Y. 2013. TRAP markers generated with resistant gene analog sequences andtheir application to genetic diversity analysis of radish germplasm. Scientia Horticulturae, vol. 161, p. 153-159. https://doi.org/10.1016/j.scienta.2013.07.004

Kallamadi, P. R., Ganga Rao Nadigatlab, V. P. R., Mulpuriba, S. 2015. Molecular diversity in castor (Ricinus communis L.). Industrial Crops and Products, vol. 66, p. 271281. https://doi.org/10.1016/j.indcrop.2014.12.061

Kanti, M., Anjani, K., Usha Kiran, B., Vivekananda, K. 2015. Agro-morphological and molecular diversity in castor (Ricinus communis L.) germplasm collected from Andaman and Nicobar Islands, India. Czech J. Genet. Plant Breed., vol. 51, p. 96-109. https://doi.org/10.17221/205/2014-CJGPB

Kumar, Y., Kwon, S. J., Coyne, C. J., Hu, J., Grusak, M. A., Kisha, T. J., McGee, R. J., Sarker, A. 2014. Target region amplification polymorphism (TRAP) for assessing genetic diversity and marker-trait associations in chickpea (Cicer arietinum L.) germplasm. Genet Resour Crop Evol., vol. 61, p. 965-977. https://doi.org/10.1007/s10722-014-0089-2

Kwon, S. J., Hu, J., Coyne, C. J. 2010. Genetic diversity and relationship among faba bean (Vicia faba L.) germplasm entries as revealed by TRAP markers. Plant Genetic Resources, vol. 8, no. 3, p. 204-213. https://doi.org/10.1017/S1479262110000201

Liu, F., Guo, Q., Shi, H., Cheng, B., Lu, Y., Goua, L., Wanga, J., Shen, W., Yan, S., Wu, M. 2016. Genetic variation in Whitmania pigra, Hirudo nipponica and Poecilobdella manillensis, three endemic and endangered species in China using SSR and TRAP markers. Gene, vol. 579, p. 172-182. https://doi.org/10.1016/j.gene.2015.12.055

Liu, F., Shi, H., Guo, Q., Lv, F., Yu, Y., Lv, L., Shen, W., Zhao, W., Zhang, M. 2015. Analysis of the genetic diversity and population structure of Perinereis aibuhitensis in China using TRAP and AFLP markers. Biochemical Systematics and Ecology, vol. 59, p. 194-203. https://doi.org/10.1016/j.bse.2015.01.002

Lu, Z., Qi, J. M., Fang, P. P., Su, J. G., Xu, J. T., Tao, A. F. 2010. Genetic diversity and phylogenetic relationship of castor germplasm as revealed by SRAP analysis. J Wuhan Bot Res., vol. 28, no. 1, p. $1-6$. https://doi.org/10.3724/SP.J.1142.2010.00001

Luo, C., Wu, H. X., Yao, Q. S., Wang, S. B., Xu, W. T. 2015. Development of EST-SSR and TRAP markers from transcriptome sequencing data of the mango. Genet. Mol. Res., vol. 14, no. 3, p. 7914-7919. https://doi.org/10.4238/2015.July.14.17

Luo, C., Zhang, F., Zhang, Q. L., Guo, D. Y., Luo, Z. R. 2013. Characterization and comparison of EST-SSR and TRAP markers for genetic analysis of the Japanese persimmon Diospyros kaki. Genet. Mol. Res. vol. 12, no. 3, p. 2841-2851. https://doi.org/10.4238/2013.January.9.3

Mei-Lian, T., Yan, M. F., Wang, L., Wang, L., Yan, X. C. 2012. Analysis of genetic diversity in castor bean by SRAP markers. J. Mong Uni Natl 2012.

Miklas, P. N., Hu, J., Grünwald, N. J., Larsen, K. M. 2006. Potential Application of TRAP (Targeted Region Amplified Polymorphism) Markers for Mapping and Tagging Disease Resistance Traits in Common Bean. Genomics, Molecular Genetics \& Biotechnology, vol. 46, no. 2, p. 910-916. https://doi.org/10.2135/cropsci2005.08-0242 
Mirajkar, S. J., Rai, A. N., Vaidya, E. R., Moharil, M. P., Dudhare, M. S., Suprasanna, P. 2017. TRAP and SRAP molecular marker based profiling of radiation induced mutants of sugarcane (Saccharum officinarum L.). Plant Gene, vol. $\quad 9, \quad$ p. $\quad 64-70$. https://doi.org/10.1016/j.plgene.2017.01.002

Mutlu, H., Meier, M. A. R. 2010. Castor oil as a renewable resource for the chemical industry. Eur. J. Lipid Technol., vol. 112, p. 10-30. https://doi.org/10.1002/ejlt.200900138

Quintero, V., Anaya-López, J. L., Núñez-Colín, C. A., Zamarripa-Colmenero, A., Montes-García, N., Solís-Bonilla, J. L., Aguilar-Rangel, M. R. 2013. Assessing the genetic diversity of castor bean from Chiapas, México using SSR and AFLP markers. Ind. Crops Prod., vol. 41, p. 134-143. https://doi.org/10.1016/j.indcrop.2012.04.033

Ražná, K., Bežo, M., Hlavačková, L., Žiarovská, J., Miko, M., Gažo, J., Habán, M. 2016. MicroRNA (miRNA) in food resources and medicinal plant. Potravinarstvo, vol. 10, no. 1, p. 188-194. https://doi.org/10.5219/583

Reddy, K. P., Nadigatla, V. P. R. G. R., Mulpuri, S. 2015. Molecular diversity in castor (Ricinus communis L.). Ind. Crops Prod., vol. 66, p. 271-281. https://doi.org/10.1016/j.indcrop.2014.12.061

Rukhsar, P. M. P., Parmar, D. J., Kalola, A. D., Kumar, S. 2017. Morphological and molecular diversity patterns in castor germplasm accessions. Ind. Crops Prod., vol. 97, p. 316-323. https://doi.org/10.1016/j.indcrop.2016.12.036

Simões, K. S., Silva, S. A., Machado, E. L. and Brasileiro, H. S. 2017a. Development of TRAP primers for Ricinus communis L. Genetics and Molecular Research, vol. 16, no. 2, p. 100-113. https://doi.org/10.4238/gmr16029647

Simões, K. S., Silva, S. A., Machado, E. L., Silva, M. S. 2017b. Genetic divergence in elite castor bean lineages based on TRAP markers. Genetics and Molecular Research, vol. 16, no. 3, p. 100-112. https://doi.org/10.4238/gmr16039776

Singh, R. B., Singh, B., Singh, R. K. 2017. Study of genetic diversity of sugarcane (Saccharum) species and commercial varieties through TRAP molecular markers. Ind. J. Plant. Physiol., vol. 22, no. 3, p. 332-338. https://doi.org/10.1007/s40502-017-0314-Z

Srivong, T., Zhu, Y. J., Sakuanrungsirikul, S., Nagai, Ch., Kosittrakun, M. 2019. Evaluating sugarcane genotypes for genetic variation with differential sucrose accumulation using TRAP markers and partial Sai nucleotide polymorphism. ScienceAsia, vol. 45, p. 309317. 1874.2019.45.309

Vasconcelos, S., Onofre, A. V. C., Milani, M., BenkoIseppon, A. M., Brasileiro-Vidal, A. C. 2016. Accessing genetic diversity levels of Brazilian genotypes of castor with AFLP and ISSR markers. Pesq Agropec Pernamb, vol. 21, p. 24-31. https://doi.org/10.12661/pap.2016.005

Vivodík, M., Balážová, Ž., Gálová, Z. and Kut'ka Hlozáková, T. 2015. Differentiation of ricin using RAPD markers. Pak. J. Bot., vol. 47, no. 4, p. 1341-1345.

Vivodík, M., Saadaoui, E., Balážová, Ž., Gálová, Z. and Petrovičová, L. 2019. Genetic diversity in Tunisian castor genotypes (Ricinus Communis L.) detected using RAPD markers. Potravinarstvo Slovak Journal of Food Sciences, vol. 13, no. 1, p. 294-300. https://doi.org/10.5219/1116

Vyhnánek, T., Trojan, V., Štiasna, K., Presinszká, M., Hřivna, L., Mrkvicová, E., Havel, L. 2015. Testing of DNA isolation for the identification of Hemp. Potravinárstvo, vol. 9, no. 1, p. 393-397. https://doi.org/10.5219/509

Wang, Ch., Li, G., Zhang, Z., Peng, M., Shang, Y., Luo, R., Chen, Y. 2013. Genetic diversity of castor bean (Ricinus communis L.) in Northeast China revealed by ISSR markers. Biochemical Systematics and Ecology, vol. 51, p. 301-307. https://doi.org/10.1016/j.bse.2013.09.017

Wang, M. L., Dzievit, M., Chen, Z., Morris, J. B., Norris, J. E., Barkley, N. A., Tonnis, B., Pederson, G. A., Yu, J. 2017. Genetic diversity and population structure of castor (Ricinus communis L.) germplasm within the US collection assessed with EST-SSR markers. Genome, vol. 60, no. 3, p. 193-200. https://doi.org/10.1139/gen-2016-0116

Weber, J. L. 1990. Informativeveness of human (dC-dA)n x (dG-dT)n polymorphism. Genomics, vol. 7, no. 4, p. 524-530. https://doi.org/10.1016/0888-7543(90)90195-Z

Yu, J., Yu, S., Lu, C., Wang, W., Fan, S., Song, M., Lin, Z., Zhang, X., Zhang, J. 2007. High-density Linkage Map of Cultivated Allotetraploid Cotton Based on SSR, TRAP, SRAP and AFLP Markers. J. Integr. Plant Biol., vol. 49, no. 5, p. 716-724. https://doi.org/10.1111/j.17447909.2007.00459.x

Yue, B., Vick, B. A., Cai, X., Hu, J. 2010. Genetic mapping for the Rf1 (fertility restoration) gene in sunflower (Helianthus annuus L.) by SSR and TRAP markers. Plant Breeding, vol. 129, p. 24-28. https://doi.org/10.1111/j.14390523.2009.01661.x

Zhang, J., Guo, Q., Zheng, D. 2013. Genetic diversity analysis of Pinellia ternata based on SRAP and TRAP markers. Biochemical Systematics and Ecology, vol. 50, p. 258-265. https://doi.org/10.1016/j.bse.2013.03.052

Žiarovská, J., Fialková, V., Zamiešková, L., Bilčíková, J., Zeleňáková, L., Kačániová, M. 2019. Expression pattern of thaumatin in the selected red varieties of Vitis vinifera, L. Potravinarstvo Slovak Journal of Food Sciences, vol. 13, no. 1, p. 547-552. https://doi.org/10.5219/1057

Žiarovská, J., Kysel', M., Cimermanová, R., Knoteková, L. 2017. Effect of DNA extraction method in the Rosa Canina L. identification under different processing temperature. Potravinarstvo Slovak Journal of Food Sciences, vol. 11, no. 1, p. 190-196. https://doi.org/10.5219/717

Žiarovská, J., Zeleňáková, L., Fernández Cusimamani, E., Kačániová, M. 2018. A thaumatin-like genomic sequence identification in Vitis Vinifera L., stormy wines and musts based on direct PCR. Potravinarstvo Slovak Journal of Food Sciences, vol. 12, no. 1, p. 226-232. https://doi.org/10.5219/892

\section{Acknowledgments:}

This work was supported by project APVV-15-0543, VEGA project No. 1/0246/18 and KEGA project No. 025SPU-4/2018.

\section{Contact address:}

*Martin Vivodík, Slovak University of Agriculture, Faculty of Biotechnology and Food Sciences, Department of Biochemistry and Biotechnology, Tr. A. Hlinku 2, 949 76 Nitra, Slovakia, Tel.: +421 37641 4269,

E-mail: martin.vivodik@ uniag.sk

ORCID: https://orcid.org/0000-0001-6265-1616

Zdenka Gálová, Slovak University of Agriculture, Faculty of Biotechnology and Food Sciences, Department of Biochemistry and Biotechnology, Tr. A. Hlinku 2, 949 76 Nitra, Slovakia, Tel.: +421 37641 4596,

E-mail: zdenka.galova@uniag.sk

ORCID: https://orcid.org/0000-0002-0349-4363 
Želmíra Balážová, Slovak University of Agriculture, Faculty of Biotechnology and Food Sciences, Department of Biochemistry and Biotechnology, Tr. A. Hlinku 2, 949

76 Nitra, Slovakia, Tel.: +421 37641 4327,

E-mail: zelmira.balazova@ uniag.sk.

ORCID: https://orcid.org/0000-0002-6093-3908

Corresponding author: * 